\title{
Adult demography of an isolated population of the threatened butterfly Scarce Heath Coenonympha hero and its conservation implications
}

\author{
Marcin Sielezniew $^{1}$ (1) $\cdot$ Piotr Nowicki ${ }^{2}$
}

Received: 17 March 2017 / Accepted: 15 July 2017 / Published online: 24 July 2017

(C) The Author(s) 2017. This article is an open access publication

\begin{abstract}
Scarce Heath Coenonympha hero is considered to be one of the most seriously threatened European butterflies, especially declining in western and central Europe. It usually occurs in small, discrete colonies forming metapopulation systems, but the exchange of individuals between habitat patches is considered limited. Therefore the persistence of the species in fragmented systems is likely to depend largely on the demography of local populations. We investigated a highly isolated population of the species in Poland with mark-release-recapture (MRR). The seasonal population size was assessed at 168 adults, with a well balanced sex ratio. The slightly higher capture probability of females that we recorded is quite atypical for butterflies and may be related to the vegetation structure at the site. The flight period was relatively short (22 days), and the adult life span was estimated at 6.59 days, i.e., twice as long when compared with adult longevity in two other threatened Coenonympha species. Consequently, the temporal fragmentation index (i.e., the ratio of flight period length to adult life span) was calculated at 3.3, which is the lowest value recorded among all congeneric species, suggesting that temporal fragmentation is not a major problem in the investigated population. Nevertheless, the population may be at risk of extinction due to its small size and isolation. Moreover, the area of $C$. hero habitat has decreased considerably over the last decade due to afforestation. Our
\end{abstract}

Marcin Sielezniew

marcins@uwb.edu.pl

1 Laboratory of Insect Evolutionary Biology and Ecology, Institute of Biology, University of Bialystok, Ciołkowskiego 1J, 15-245 Białystok, Poland

2 Institute of Environmental Sciences, Jagiellonian University, Gronostajowa 7, 30-387 Kraków, Poland findings indicate the need for immediate conservation actions, in particular for the removal of tree seedlings that encroach on the butterfly habitat.

Keywords Flight period · Life span · Mark-recapture · Protandry $\cdot$ Sex ratio $\cdot$ Temporal fragmentation

\section{Introduction}

In highly fragmented European landscape many butterfly species live on fragmented sites supporting small populations which are at risk of extinction due to demographic and environmental stochasticity as well as inbreeding (Lande 1988; Saccheri et al. 1998). Isolated and vulnerable populations are often subject of special conservation concern and simultaneously attract remarkable scientific attention (e.g. Konvicka et al. 2005, 2008a, b). Thorough knowledge on species ecology is vital in the context of effective conservation (Thomas et al. 2009).

One of the very local and declining species in Europe is the Scarce Heath Coenonympha hero (Linnaeus, 1761) (Lepidoptera, Nymphalidae). The butterfly despite its wide Eurosiberian range is considered to be one of the most threatened European species, classified as vulnerable (VU) both in Europe and the European Union, and listed in Appendix II of the Bern Convention, as well as Appendix IV of the Habitats Directive (Van Swaay et al. 2010). The species is especially declining in western and central Europe, and it has already become extinct in the Czech Republic, Denmark, Luxembourg, and the Netherlands (Meyer 1996; Van Swaay and Warren 1999; Beneš et al. 2002; Kudrna et al. 2011). Geographical location in combination with spatial isolation have caused the erosion of the gene pool of some peripheral populations 
(Cassel and Tammaru 2003). More stable populations occur in the eastern part of the continent e.g., in Belarus, Russia and the Baltic States (Van Swaay and Warren 1999). On a continental scale, $C$. hero is potentially threatened by climate change (Settele et al. 2008).

This small butterfly (with a wing span of about $3 \mathrm{~cm}$ ) inhabits clearings in wet, usually deciduous forests, and on wet meadows with scattered trees, as well as ecotones on the edges of forests and wet meadows or fens (Meyer 1996; Van Swaay and Warren 1999). Its preffered habitats used to be created naturally by fires, windfalls and grazing by large herbivores. Coenonympha hero is a univoltine species which is on the wing from mid-May to mid-July depending on the locality (Meyer 1996). The butterflies are relatively sedentary and do not fly for long distances (Cassel-Lundhagen and Sjögren-Gulve 2007). Males are patrollers and they can be observed flying slowly, low over the vegetation. Females usually lay their eggs on dry plants close to the ground (Cassel-Lundhagen et al. 2008). Caterpillars feed on various grasses including Deschampsia caespitosa, Calamagrostis epigejos, Brachypodium sylvaticum, and Elymus caninus (Meyer 1996). In breeding experiments, other species were also accepted as larval foodplants, e.g., Festuca ovina and Dactylis glomerata (Cassel et al. 2001). However, Tiitsaar et al. (2016) suggest that microclimatic conditions are more important determinants of habitat quality than the presence of specific host plants. Larvae overwinter in the 3rd instar in grass tussocks, and they resume their growth in early spring to pupate finally in the 5 th instar in May (Cassel-Lundhagen et al. 2008).

Coenonympha hero usually occurs in discrete small colonies, forming metapopulation systems. As predicted by metapopulation theory, patch area as well as distance to the nearest large population proved to be the key predictors of species presence/absence in local habitat patches (Cassel-Lundhagen et al. 2008). In addition, studies carried out in Sweden documented the limited dispersal ability of the species, and consequently little exchange of individuals between habitat patches (CasselLundhagen and Sjögren-Gulve 2007). In such a situation one might expect that species persistence in fragmented systems would be more dependent on the demography of local populations and less on the dispersal among them. However, the adult demography of $C$. hero has not yet been adequately studied. The aim of the present study was to fill this gap by investigating a highly isolated population of the species in Poland, where it is in decline and endangered by extinction (Sielezniew 2012). We sought to determine if adult life span, protandry, or limited movement among habitat patches were potential factors that could be limiting the current population.

\section{Materials and methods}

\section{Study site}

We conducted our study on an isolated site of $C$. hero near Łosiniany $\left(53^{\circ} 11^{\prime} \mathrm{N} ; 23^{\circ} 51^{\prime} \mathrm{E}\right)$ in the Knyszyn Forest (NE Poland), which is one of the Prime Butterfly Areas in the country (Buszko 2003). The investigated population was only discovered in 2014, and it remains the only one identified in the area. The nearest known localities of $C$. hero in Poland are situated in the Biebrza Valley, i.e., about $80 \mathrm{~km}$ westwards (Sielezniew 2012).

The butterfly inhabited three meadow fragments (a total area of about 0.95 ha) (Fig. 1a), which could be classified as eutrophic fen meadows (Calthion palustris) and were rich in tall herbs, e.g., Bistorta major, Cirsium rivulare, Lychnis flos-cuculi, Tribula terrestris and Ranunculus spp. The fragments of $C$. hero habitat were separated by narrow strips of forest, dominated by alders. About $60 \%$ of the largest $(0.45 \mathrm{ha})$ and the outermost
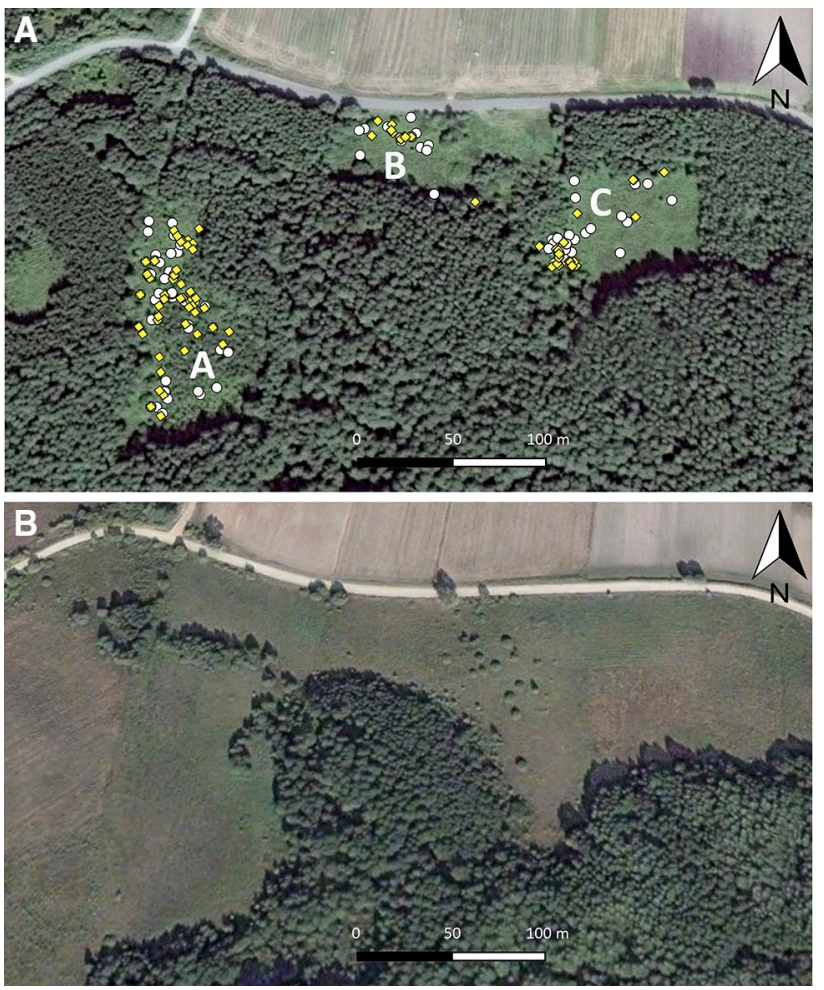

Fig. 1 Orthophotomap of the study site, and the distribution of male (yellow diamonds) and female (white circles) captures of $C$. hero in 2015 (a). The capital letters indicate the three separate meadow fragments. The orthophotomap of the site in 2003 (b) is also presented so as to document the rapid changes in habitat composition, namely the spreading of forest. Source of orthophotomaps: Digital Globe (acquired through Google Earth). (Color figure online) 
west fragment was afforested about 3-4 years earlier, and it is currently covered by deciduous tree seedlings (mainly oaks and hornbeams). No signs of other recent management could be seen. Surprisingly, $C$. hero was not observed on any other meadow in the vicinity, despite their very similar vegetational characteristics.

\section{Data collection}

We used a mark-release-recapture (MRR) study to estimate population size, adult life span, and exchange of individuals between habitat patches. We sampled the population in 2015 on 16 occasions between 1 and 22 June, with markrelease-recapture (MRR). The sampling covered the entire flight period of the focal species, and the site was visited almost every day if the weather was favourable (i.e., sunny and not very windy), between $10 \mathrm{am}$ and $5 \mathrm{pm}$. One or two people spent about $2 \mathrm{~h}$ on the site during each sampling day. Every time all three meadow fragments were explored one by one. Butterflies were captured with an entomological net, marked on the underside of their hind-wings with unique identity numbers using a fine-tipped waterproof pen, and then immediately released at the place of capture. Date, time and GPS coordinates of each (re)capture as well as sex and ID number of each butterfly were recorded.

\section{Analysis}

We analysed our data with the Jolly-Seber model (Arnason and Schwarz 1999) using the program MARK, version 8.0 (White and Burnham 1999). The model represents a wellestablished standard for estimating population size in open populations, and it has been frequently applied in butterfly studies (Schtickzelle et al. 2002; Nowicki and Vrabec 2011; Osváth-Ferencz et al. 2017). Based on the lowest value of the Akaike Information Criterion corrected for small sample size $\left(\mathrm{AIC}_{\mathrm{c}}\right)$ (Hurvich and Tsai 1989), the bestperforming model variant was $\varphi() p.(s+t) B\left(s^{*} t\right)$, i.e., the model assuming a constant (and equal for both sexes) survival rate $(\varphi)$, but sex-dependent and freely time-varying (thus differing between capture days) recruitments of new individuals into the population $(B)$, and sex-dependent and time-varying capture probabilities $(p)$ with a constant difference between sexes. We thus used this model to obtain the estimates of daily numbers of males and females as well as their seasonal population sizes. Subsequently, we estimated the total population size as the sum of the male and female population sizes estimated from the best model. For comparative purposes we also derived mean capture probabilities for males and females across the entire season as well as mean adult life span, estimated from survival rate as $e=(1-\varphi)^{-1}-0.5$ (Nowicki et al. 2005). Besides, we calculated the temporal fragmentation index, i.e., ratio of flight period length to adult life span, which is considered a useful indicator of species vulnerability (Bubová et al. 2016).

In addition, we used the multi-state recapture model of Brownie et al. (1993) in MARK 8.0 to assess the probabilities of butterfly movements $(\psi)$ between the three discrete meadow fragments. Although the temporal variation and intersexual differences in movement probability might be of interest (cf. Timus et al. 2017), accounting for them was not possible, since due to the small sample size of recaptured individuals, it would have led to the overparametrisation of the model. Consequently, we had to disregard these potential effects, and we restricted our analysis to the estimation of constant and sex-independent probabilities of movements between each pair of meadow fragments.

\section{Results}

We captured and marked a total of 101 individuals (52 males and 49 females). About half i.e., 54 (27 of each sex) were recaptured. The maximum number of recaptures on different days for an individual was 6 for females and 4 for males. Most of the capture events occurred in more sheltered places, neighboured by trees and shrubs (Fig. 1).

The mean number of days between the first and last capture was 4.15 for males and 3.93 for females respectively, whereas the maximum duration between captures of an individual reached 9 and 10 days respectively for both sexes. The daily survival rate obtained with the Jolly-Seber model was 0.859 (95\% CI 0.812-0.896), which corresponds to the estimated adult life span of 6.59 days (95\% CI 4.82-9.12 days). Taking into consideration the the recorded flight period (22 days) the temporal fragmentation index was estimated at 3.3 .

The mean capture probability was slightly higher in females $(0.341 \pm 0.047 ; 95 \%$ CI $0.255-0.439)$ than in males $(0.244 \pm 0.040$; $95 \%$ CI $0.175-0.330)$. Protandry was evident, although relatively weak, with the emergence of males preceding that of females only by 2-3 days (Fig. 2). The peaks in male and female occurrence coincided on June 8th, but after that date the estimated daily numbers of males dropped more rapidly than females (Fig. 2). The seasonal population size was estimated at 168 adults $(95 \%$ CI 119-348), with a fairly well-balanced sex ratio, i.e., 89 males (95\% CI 60-217) and 79 females (95\% CI 53-252).

We recorded 14 movements of 12 butterflies (i.e., 22\% of recaptured individuals) among the three defined meadow fragments. The estimated movement probabilities between these fragments were quite substantial, exceeding $10 \%$ in most cases (Table 1), which indicates a fragmented, but still relatively well-connected population. 


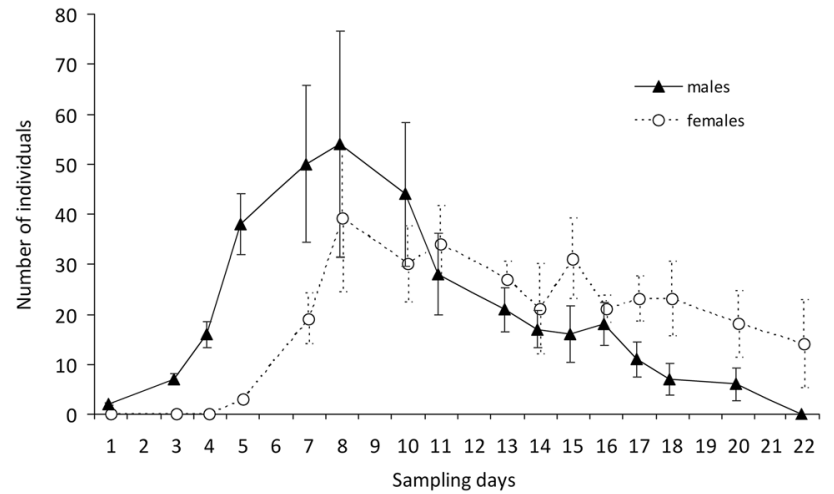

Fig. 2 Dynamics of daily numbers of males and females throughout the flight period based on Jolly-Seber model estimates. Error bars represent SEs. It should be noted that no butterflies were observed after 22 June

Table 1 The probabilities of Coenonympha hero movements (with their SEs) between the three defined meadow fragments, estimated with the multi-state recapture model of Brownie et al. (1993)

\begin{tabular}{lllll}
\hline From & To & \multicolumn{2}{l}{ Meadow } & \\
\cline { 3 - 5 } & & $\mathrm{A}$ & $\mathrm{B}$ & $\mathrm{C}$ \\
\hline Meadow & $\mathrm{A}$ & - & $0.436( \pm 0.085)$ & $0.032( \pm 0.031)$ \\
& $\mathrm{B}$ & $0.274( \pm 0.072)$ & - & $0.109( \pm 0.064)$ \\
& $\mathrm{C}$ & $0.112( \pm 0.084)$ & $0.126( \pm 0.078)$ & - \\
\hline
\end{tabular}

\section{Discussion}

It has recently been found that many threatened butterflies in Europe are characterised by short-lived adults (Bubová et al. 2016). In this context, it is interesting to note that the adult life span estimated in our study for $C$. hero is twice as long as adult longevity in two other threatened Coenonympha species i.e., C. oedippus and C. tullia (reaching 3 days on average) (Turner 1963; Örvössy et al. 2013), and similar to that of the common and widespread C. pamphilus (Wickman 1985). The calculated value of the temporal fragmentation index was the lowest among all congeneric species, and one of the lowest of all the European butterflies studied so far. This was rather unexpected as species of conservation concern are typically characterized by higher values of this index (see review by Bubová et al. 2016). Hence this result, especially in combination with relatively weak protandry, suggests that temporal fragmentation, i.e., reduced effective population size due to the fact that individuals flying in different parts of the season do not have the chance to mate with one another (Nowicki et al. 2005), is not a serious problem in the investigated population.

Concerning sex ratio, our findings are consistent with the results of breeding experiments on $C$. hero, which indicated that the proportions of males and females were fairly balanced (Cassel-Lundhagen and Sjögren-Gulve 2007). However, slightly higher capture probability of females that we recorded is quite atypical for butterflies, including Coenonympha species (cf. Cassel-Lundhagen and Sjögren-Gulve 2007; Örvössy et al. 2013). Usually males are encountered and captured much more frequently, since they spend a larger proportion of time flying than females (Nowicki et al. 2008; Osváth-Ferencz et al. 2017). Accordingly, Cassel-Lundhagen and Sjögren-Gulve (2007) reported a higher mobility of $C$. hero males, and they captured twice as many males as females. An explanation for the different pattern in our study may be related to the vegetation characteristics of our study site, which was covered by many tall herbs and young trees. Therefore patrolling males, flying low, could be more difficult to detect. It is worth mentioning that at some other sites of the species in NE Poland (Biebrza National Park) characterized by low vegetation, males are recorded more frequently than females during transect counts (M. Sielezniew, unpublished data).

Despite the positive features discussed above, i.e., low temporal fragmentation and balanced sex ratio, the investigated population may be at risk of extinction given the small population size ( $<200$ adults) and isolation (cf. Thomas and Hanski 1997). Nevertheless, it is still of high importance for the preservation of $C$. hero in Poland, where the species is declining, and assessed as endangered. It has already disappeared from the west of the country, and at the moment it occurs only in a few dozen sites in the southern and north-eastern regions (Sielezniew 2012). It should be underlined that the investigated population is potentially one of the largest in the latter region (M. Sielezniew, unpubl. data), and $C$. hero recently became extinct in another Prime Butterfly Area in NE Poland, the Białowieża Forest (Jaroszewicz 2010).

Our 1-year study does not enable the evaluation of the long-term trend of the investigated population. However, the analysis of the available orthophotomaps (Fig. 1) indicates that the area of the $C$. hero habitat apparently decreased considerably (by ca. 60\%) in the last decade, due to afforestation. The three meadow fragments that make up the site at present were not separated in the past. Moreover, the part of the $C$. hero habitat in Łosiniany that was recently forested is likely to disappear in coming years following tree growth, and as a result the habitat size will be further reduced by at least $30 \%$. Moreover this ill-conceived afforestation will cause the connectivity of the three meadow fragments to deteriorate, and thus although at present the exchange of butterflies between them is relatively high, it may not be so in the near future, which will further decrease the survival chances of the focal population. Populations of other priority species, i.e., Lycaena helle (listed in the Habitats Directive) and Boloria eunomia (threatened 
in central Europe), simultaneously recorded on the site (M. Sielezniew, unpublished data), will be also affected.

Consequently, the removal of young trees, the growth of which will lead to excessive shade within a few years, seems the most urgently needed management action for the site. However, achieving this goal seems unlikely given the reality of the current forest management. A more feasible step seems to be the research focused on solving the puzzle of the extremely local presence of $C$. hero despite its relatively wide spectrum of potential larval food plants. The identification of the preferences of both ovipositing females and feeding caterpillars would definitely help in defining further vital actions for the effective conservation of the species. In addition, a monitoring of the focal population is worth to be started in order to provide the information about its interannual trends. This should give the answer to the question of whether the population is indeed in a serious decline or perhaps small but stable.

Acknowledgements Krzysztof Deoniziak helped in the field studies. The analysis was supported by the Polish National Science Centre Grant DEC-2013/11/B/NZ8/00912. Sarah Łuczaj made linguistic improvements on the manuscript. The Regional Director for Environmental Protection in Białystok provided permission for the markrelease-recapture sampling of $C$. hero. Two anonymous reviewers made valuable comments on the manuscript.

\section{Compliance with ethical standards}

Conflict of interest The authors declare that they have no conflict of interest.

Ethical approval The authors declare that they have complied with ethical standards.

Open Access This article is distributed under the terms of the Creative Commons Attribution 4.0 International License (http:// creativecommons.org/licenses/by/4.0/), which permits unrestricted use, distribution, and reproduction in any medium, provided you give appropriate credit to the original author(s) and the source, provide a link to the Creative Commons license, and indicate if changes were made.

\section{References}

Arnason AN, Schwarz CJ (1999) Using POPAN-5 to analyse banding data. Bird Study 46:157-168

Beneš J, Konvička M, Dvořák J, Fric Z, Havelda Z, Pavlíčko A, Vrabec V, Weidenhoffer Z (eds) (2002) Motýli České republiky: Rozšîrení a ochrana, I, II. SOM, Praha

Brownie C, Hines JE, Nichols JD, Pollock KH, Hestbeck JB (1993) Capture-recapture studies for multiple strata including nonMarkovian transitions. Biometrics 49:1173-1187

Bubová T, Kulma M, Vrabec V, Nowicki P (2016) Adult longevity and its relationship with conservation status in European butterflies. J Insect Conserv 20:1021-1032

Buszko J (2003) Poland. In: van Swaay CAM Warren M (eds) Prime butterfly areas in Europe. Priority sites for conservation National
Reference Centre for Agriculture, Nature and Fisheries, Ministry of Agriculture, Nature Management and Fisheries, The Netherlands, pp 399-401

Cassel A, Tammaru T (2003) Allozyme variability in central, peripheral and isolated populations of the scarce heath (Coenonympha hero: Lepidoptera, Nymphalidae); implications for conservation. Conserv Genet 4:83-93

Cassel A, Windig J, Nylin S, Wiklund C (2001) Effects of population size and food stress on fitness-related characters in the scarce heath, a rare butterfly in Western Europe. Conserv Biol 15:1667-1673

Cassel-Lundhagen A, Sjögren-Gulve P (2007) Limited dispersal by the rare scarce heath butterfly: potential consequences for population persistence. J Insect Conserv 11:113-121

Cassel-Lundhagen A, Sjögren-Gulve P, Berglind S-Ã (2008) Effects of patch characteristics and isolation on relative abundance of the scarce heath butterfly Coenonympha hero (Nymphalidae). J Insect Conserv 12:477-482

Hurvich CM, Tsai C (1989) Regression and time series model selection in small samples. Biometrika 76:297-307

Jaroszewicz B (2010) Stan zachowania na terenie Puszczy Białowieskiej gatunków motyli z załączników II i IV Dyrektywy Siedliskowej i propozycje działań ochronnych. Parki nar Rez Przyr 29:29-50

Konvicka M, Cizek O, Filipova L, Fric Z, Benes J, Krupka M, Zamecnik J, Dockalova Z (2005) For whom the bells toll: demography of the last population of the butterfly Euphydryas maturna in the Czech Republic. Biologia 60:551-557

Konvicka M, Benes J, Cizek O, Kopecek F, Konvicka O, Vitaz L (2008a) How too much care kills species: grassland reserves, agri-environmental schemes and extinction of Colias myrmidone (Lepidoptera: Pieridae) from its former stronghold. J Insect Conserv 5:519-525

Konvicka M, Novak J, Benes J, Fric Z, Bradley J, Keil P, Hrcek J, Chobot K, Marhoul P (2008b) The last population of the Woodland Brown butterfly (Lopinga achine) in the Czech Republic: habitat use, demography and site management. J Insect Conserv 12:549-560

Kudrna O, Harpke A, Lux K, Pennerstorfer J, Schweiger O, Settele J, Wiemers M (2011) Distribution atlas of butterflies in Europe. Gesellschaft für Schmetterlingschutz, Halle

Lande R (1988) Genetics and demography in biological conservation. Science 241:1455-1460

Meyer M (1996) Coenonympha hero (Linnaeus, 1761). In: Helsdingen PJ, van Willemse LPM, Speight MCD (eds) Background information on invertebrates of the Habitats Directive and the Bern Convention. Part I: Crustacea, Coleoptera and Lepidoptera. Nature and environment, No. 79. Council of Europe, Strasbourg, pp 93-97

Nowicki P, Vrabec V (2011) Evidence for positive density-dependent emigration in butterfly metapopulations. Oecologia 167:657-665

Nowicki P, Witek M, Skorka P, Settele J, Woyciechowski M (2005) Population ecology of the endangered butterflies Maculinea teleius and $M$. nausithous and the implications for conservation. Popul Ecol 47:193-202

Nowicki P, Settele J, Henry P-Y, Woyciechowski M (2008) Butterfly monitoring methods: the ideal and the real world. Isr J Ecol Evol 54:69-88

Örvössy N, Kőrösi Á, Batáry P, Vozár A, Peregovits L (2013) Potential metapopulation structure and the effects of habitat quality on population size of the endangered False Ringlet butterfly. J Insect Conserv 17:537-547

Osváth-Ferencz M, Bonelli S, Nowicki P, Peregovits L, Rákosy L, Sielezniew M, Kostro-Ambroziak A, Dziekańska I, Kőrösi A (2017) Population demography of the endangered large blue butterly Maculinea arion in Europe. J Insect Conserv 21:411-422 
Saccheri I, Kuussaari M, Kankare M, Vikman P, Fortelius W, Hanski I (1998) Inbreeding and extinction in a butterfly metapopulation. Nature 392:491-494

Schtickzelle N, Le Boulenge E, Baguette M (2002) Metapopulation dynamics of the bog fritillary butterfly: demographic processes in a patchy population. Oikos 97:349-360

Settele J, Kudrna O, Harpke A, Kühn I, van Swaay C, Verovnik R, Warren M, Wiemers M, Hanspach J, Hickler T, Kühn E, van Halder I, Veling K, Vliegenthart A, Wynhoff I, Schweiger O (2008) Climatic risk atlas of European butterflies. Pensoft, Sofia-Moscow

Sielezniew M (2012) Strzępotek hero Coenonympha hero. In: Makomaska-Juchiewicz M, Baran $\mathrm{P}$ (eds) Monitoring gatunków zwierząt. Przewodnik metodyczny. Część II. GIOŚ, Warszawa, pp 274-289

Thomas CD, Hanski I (1997) Butterfly metapopulations. In: Hanski I, Gilpin ME (eds) Metapopulation biology: ecology, genetics, and evolution. Academic Press, San Diego, pp 359-386

Thomas JA, Simcox DJ, Clarke RT (2009) Successful conservation of a threatened Maculinea butterfly. Science 325:80-83

Tiitsaar A, Kaasik A, Lindman L, Stanevitš T, Tammaru T (2016) Host associations of Coenonympha hero (Lepidoptera: Nymphalidae) in northern Europe: microhabitat rather than plant species. J Insect Conserv 20:265-275
Timus N, Czekes Z, Rákosy L, Nowicki P (2017) Conservation implications of source sink dynamics within populations of endangered Maculinea butterflies. J Insect Conserv 21:369-378

Turner J (1963) A quantitative study of a Welsh colony of the large heath butterfly, Coenonympha tullia Müller (Lepidoptera). In: Proceedings of the Royal Entomological Society of London. Series A, General Entomology, vol 7-9. Wiley Online Library, New York, pp 101-112

Van Swaay CAM, Warren MS (1999) Red data book of European butterflies (Rhopalocera). Nature and Environment Series No. 99. Council of Europe, Strasbourg

Van Swaay C, Cuttelod A, Collins S, Maes D, Munguira ML, Šašić M, Settele J, Verovnik R, Verstrael T, Warren M, Wiemers M, Wynhoff I (2010) European red list of European butterflies. Publication Office of the European Union, Luxembourg

White GC, Burnham KP (1999) Program MARK: survival estimation from populations of marked animals. Bird Study 46:120-138

Wickman PC (1985) The influence of temperature on the territorial and mate locating behaviour of the small heath butterfly, Coenonympha pamphilus (L.) (Lepidoptera: Satyridae). Behav Ecol Sociobiol 16:233-238 